to the same legislative end. What new element is added by the grant of an ostensible option between this aggravated common-law liability and the scheme of insurance or of liability without fault? The allowance of a degree of latitude in the character and conditions of redress indicates no change in the direction of the legislative purpose. This is the more evident in view of the fact that the option granted, at least so far as the employer is concerned, is not and is not intended to be a real one, but the aggravated common-law liability is designed to coerce the employer into the acceptance of the ostensible alternative. As evidence of the dominant legislative intention this fictitious option should not be regarded otherwise than as a penal sanction.

While the important consideration is that a consistent and so far as possible uniform theory of the workmen's compensation statutes should prevail, ${ }^{20}$ it is submitted that this end can be best achieved by starting with an interpretation which accords with the motives underlying the legislation. This requirement is clearly not met by the contract theory unfortunately prevailing.

\title{
FURTHER LIMITATIONS UPON FEDERAL INCOME TAXATION
}

The decision of the United States Supreme Court denying the taxability of stock dividends as income under the Sixteenth Amendment ${ }^{1}$ aroused a fever of interest before it was announced, culminating in the stock market flurry caused by the erroneous first report of it. $^{2}$ Since its announcement it has been the subject of extensive comment, both favorable and adverse. ${ }^{3}$ It seems, however, to have been rather

${ }^{3}$ See also Comment (IgI7) 27 Yale Law Journas, irz.

${ }^{1}$ Eisner v. Macomber (Ig20, U. S.) 40 Sup. Ct. I\&g.

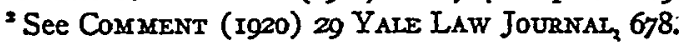

- See article by the writer hereof, Eimer v. Macomber (1920) 29 YALE LAW Journax, 735. The soundest suggestion for upholding any part of the tax upon stock dividends is given by Professor Warren, Taxability of Stock Dividends as Income (1920) 33 HARV. L. REv. 885. In effect, it is that accrued increases in value of capital items are taxable and that Congress has the power to state, and has here stated, what shall be the test to show that such gains have accrued. But, it may be suggested: (I) that, as Professor Warren states, this would at most only sustain the tax so far as levied upon the increase in value taking place while the recipient of the stock dividend holds the stock, and would leave so little of the actual statute left and so unfair a resulting situation as to make it questionable whether any of the statute should be upheld under such conditions; (2) that declaring of a stock dividend by no means signifies an increase in value to the extent of the book value of the stock dividend-that being the taxable amount [Art. 1545 of (1919) U. S. Int. Rev., Reg. 45]-but is ordinarily a suggestion of a present partial increase and an augury of further increase in market value; and (3) that the declaration of a stock dividend may conceivably be an expression of the opinion of the directors of the corporation that an increase in value has taken place, but is no more an actual realization of a monetary gain to the stockholder than a raise in a tax assessment by a board of assessors is such a realization to the taxpayer. 
generally thought a blow to government revenues." A few weeks later the same Court without apparently stirring a ripple of interest announced a decision which to the mind of the writer hereof will mean an infinitely greater loss in revenue to the government and will have an infinitely greater effect upon our scheme of income taxation as a whole. In Evans v. Gore (1920, U. S.) 40 Sup. Ct. 550, which decided that the salary of a federal judge was not taxable as income, the court finally settled decisively that the Sixteenth Amendment added no new fields of taxation to those within the power of the federal government and expressly placed beyond the reach of that government all income received either as salary or interest on indebtedness from the various states and their local subdivisions. The opinion was by Justice Van Devanter. Justice Holmes filed a dissenting opinion, in which Justice Brandeis concurred.

There are two possible reasons for the lack of interest in this case: one was that the particular question involved, recovery by a federal judge of an income tax paid upon his salary, was of course of limited scope and the larger question was only to be perceived upon a study of the opinion; and the other was that many have doubtless felt the non-taxability of state securities to be well settled. Moreover, the particular question also involved a consideration of another point, namely the effect of the constitutional prohibition against diminishing the compensation of a federal judge during his continuance in office. ${ }^{5}$

It is true that the history of the Sixteenth Amendment and the decisions under it gave much ground for this belief as to the question of the taxability by the federal government of income received from a state or its subdivisions. ${ }^{6}$ Prior to the Amendment it had been held, apparently without serious conflict of opinion, that as the power to tax was the power to destroy, Congress had no power of taxation over any instrumentalities of a state. "When the Sixteenth Amendment was proposed to the states, Governor Hughes of New York asked the' assembly of that state to reject it on the ground that it gave such

That the effect of Eisner v. Macomber, supra, upon government receipts will not in the long run necessarily be large, see (1920) 29 YALE LAW JoURNAL, 738.

${ }^{5}$ Art. III, sec. I, of the Constitution. The salary of the President is subject to a similar safeguard. Art. II, sec. $x, \mathrm{cl} .6$. The same question is there involved.

'See (1920) 29 Yale Law Journar, 735, 740, 74I. See also A. C. Ritchie, Power of Congress to Tax State Securities, (I9I9) 5 AM. BAR Ass'N. Jour. 602; cf. Harry Hubbard, The Sixteenth Amendment, (I920) 33 HARv. L. REv. 794.

"Collector v. Day (1870, U. S.) II Wall. II3, II4 (state salaries not taxable); United States v. Baltimore \& Ohio Ry. (I872, U. S.) I7 Wall. 322 (municipal bonds not taxable; two justices dissenting, one justice abstaining from decision); Pollock v. Farners Loan \& Trust Co. (1895) I57 U. S. 429, I5 Sup. Ct. 673, (1895) I58 U. S. 601, 15 Sup. Ct. 912, Ambrosina v. United States (1902) I87 U. S. I, 23 Sup. Ct. I2; Farmer's, etc., Bank v. Mimnesota (Ig14) 232 U. S. 516, 34 Sup. Ct. 354. Cf. South Carolina v. United States (Ig05) 199 U. S. 437, 26 Sup. Ct. II, upholding a tax upon a non-governmental agency of a state. 
power to Congress and thus jeopardized the future existence of the states. This called forth so much adverse comment at the time as to lead the Supreme Court in the principal case to say that "the apprehension was effectively dispelled and ratification followed." And finally the Supreme Court has previously said in several cases that the Amendment gave no new taxing power to Congress, but merely removed a disability that hindered the method of levying a certain kind of tax. ${ }^{8}$ Nevertheless, the question could not be considered definitely settled until a decision had expressly considered the point, for there had been some noteworthy accord with Governor Hughes' views, ${ }^{9}$ and the question had been considered so far open that it was debated in Congress at the time when the income tax bill of I9I8 was under consideration. ${ }^{10}$ Only last spring a powerful argument was made in a law review article for the position now repudiated by the majority of the Court, and its reasoning was accepted in toto by the dissenting justices. ${ }^{11}$

It was necessary for the Court to pass upon this matter, since it first came to the conclusion, discussed hereafter, that under the original Constitution the salaries of the federal judges could not be subject to an income tax..$^{12}$ Then the question arose whether the Sixteenth Amendment by referring to "incomes from whatever source derived"13 had given such additional power to the federal government,

${ }^{3}$ Brushaber v. Union Pacific Ry. (Ig16) 240 U. S. I, 36 Sup. Ct. 236; Stanton v. Baltic Mining Co. (1916) 240 U. S. 103, 36 Sup. Ct. 278 ; Peck v. Lowe (Ig18) 247 U. S. 165, 38 Sup. Ct. 432. See Ballantine, Constitutional Aspects of the Excess Profits Tax (Ig20) 29 Yale Law Journal, 625. 628, and cf. comment on these cases as dicta by Hubbard, op. cit. supra, note 6 .

- Citations are given in Ritchie, op. cit. supra, note 6. See Professor R. C. Minor, The Proposed Income Tax Amendment (I9I0) I5 VA. LAw REG. 737, 753; A. C. Graves, Inherent Improprieties in the Income Tax Amendment (IgIo) Ig Yale Law JournaI, 505, 528; Governor A. E. Willson of Kentucky, The Income Tax Amendment (IgII) 43 CHr. LEG. NEwS, 25I, quoting from a letter of Governor Hughes.

${ }^{10}$ The House supported such a measure, but the Senate did not. See Ritchie, op. cit. supra, note 6 . The language of the present Act, however, is broad enough to include incomes from salaries of state and local officials and apparently in the view of the Senate Finance Committee the constitutional question was to be raised. Montgomery, Income Tax Procedure, (1920) 268, 269. The Attorney General has, however, ruled against the collection of a tax on such income. (I9I9) 3I Op. Atty. Gen. 44I. Senator Knox supported the constitutionality of a tax on the income of state securities under the war powers of the government. Cong. Rec. (65th Cong., 2d sess.) 11854, II859-1186I. See arguments contra of Senator Kellogg, id. 12179, and of Professor Taft, id. I2451.

${ }^{11}$ Hubbard, op. cit. supra, note 6.

${ }^{12}$ Under the provisions cited in note 5, supra.

13 "The Congress shall have power to lay and collect taxes on incomes, from whatever source derived, without apportionment among the several states, and without regard to any census or enumeration." The words in italics did not appear in the original amendment proposed in Congress, but the wording was, "direct taxes upon incomes." See Hubbard, op. cit. supra, note 6. 
a question the answer to which, as the court expressly states, decides the question of the taxability of all incomes received from the states. ${ }^{14}$

Quite probably the words quoted from the Amendment were inserted in part at least to blot out all distinctions between incomes from different sources. The famous Pollock case had suggested such distinctions, stating that a tax on the gains or profits from business, privileges, or employments as distinguished from income from real and personal property and the like, might be sustained as an "excise tax."15 Nevertheless, there is nothing in such history to demand a decision that these words add nothing to the previous definitions by the Court of taxable income. On the contrary, the ordinary meaning of the all-inclusive words used would seem to demand the opposite construction, namely one including all kinds of income, no matter from what source derived. The decision unduly limits the words used in the Amendment, a limitation which it attempts to justify by defining the purpose of the Amendment as in effect to remove the restrictions stated in the Pollock case, i. e. the requirement of apportionment. It is submitted that there is nothing in this historical background to make necessary the attributing of such a limited purpose to the framers of the Amendment and to require the consequent restriction of the plain language of the Amendment. The arguments to be drawn from certain facts, namely, that the Pollock case also held taxes upon municipal bonds invalid, and that the wording of the amendment was changed in Congress to include the broader designation of income, point the other way. ${ }^{18}$

There is another view which lends weight to a contrary construction of the Amendment and even makes doubtful the court's view of the law irrespective of the Amendment. That is the question how far for the purpose of a tax figured on a general balance struck after adding all gains and subtracting all proper deductions for the year it is possible or permissible to consider such balance as composed of items from separate sources. As Mr. Justice Holmes in his dissent puts it, at some point money received as salary loses its specific character as such and becomes intermingled with the general funds of the owner. Thus, if put into a house, the house of the judge is not tax-exempt,

\footnotetext{
"Since, in the view of the cases cited in note 7, supra, such income was taxable, if at all, only under the Sixteenth Amendment.

${ }^{15}$ See Pollock v. Farmers' Loan and Trust Co. (1895) 158 U. S. 601, 635, 15 Sup. Ct. 912,920 .

${ }^{20}$ It should be remembered that in the Pollock case the Court held, five to four, that taxes on income from property were direct taxes and hence required equal apportionment, and further held unanimously that taxes on income from state securities were beyond the power of Congress. The Act under consideration there was improper for both reasons. The latter portion of the Sixteenth Amendment would remove the first objection, while the words in italics, especially in view of the change from the original form proposed (see note 13, supra), would be surplusage unless they remove the second objection.
} 
and so if converted into other things subject to taxation, e. g. playing cards subject to the federal government's excise tax. There seems to be no reason why a man's income may not be treated as one entire fund for the year, and it is reasonable to suppose an intention of the framers of the Amendment to do away with all questions of its derivation so long only as it is income.

This argument had been well developed by the government to meet the contention that the tax violated the Constitution because it diminished the judge's compensation during his term of office, and it had met with the approval of the lower court. ${ }^{17}$ Moreover the Attorney General in a well-reasoned opinion given last year had argued that the tax, at most, had "increased the cost of living by creating a new obligation of citizenship, to the discharge of which a part of the salaries must be devoted." 18 Here, too, admitting all that the majority say as to the vital necessity of an independent judiciary, it seems hard to justify their construction of the constitutional provision as to the diminishing of compensation. They properly hold it was intended primarily for the benefit of the public to secure a proper judiciary, and was not designed for the benefit of the individual judges. Hence the purpose involved was to prevent any legislative attacks upon the judges' livelihood which might render them subservient to that branch of the government. It is difficult to see how the distribution of the burdens of government over all the citizenry without discrimination is going to have any particular effect in destroying the independence of the judiciary. ${ }^{19}$

Such a view of income as a blended mass the Court had tended to foster by certain of its decisions under the Amendment. Thus it had held that a tax levied upon the income of a corporation of which more than two thirds was derived from exports did not violate the pro-

${ }^{17}$ Evais v. Gore (1919, N. D. Ky.) 262 Fed. 550, approved in (rger) I8 MicH. L. REv. 698 .

${ }^{13}$ (1919) 3 I Op. Atty. Gen. 475, 484. The Attorney General, as well as counsel for the government and the court below, had felt it necessary to concede, in view of the cases cited in note 8, supra, that the Sixteenth Amendment gave no new taxing power to Congress. The dissent indicates that the concession was unwise.

${ }^{10}$ See citations in notes $I 7$ and 18 , supra, and see especially 262 Fed. 552. The Supreme Court's construction of section I of Article III appears to coincide with the views of Chief Justice Taney, expressed in a letter of protest to the Secretary of the Treasury, (1863) I57 U. S. 701; with the opinion of Attorney General Hoar, (1869) 13 Op. Atty. Gen. I6r; and with the views of Mr. Justice Field in the Pollock case, (1894) I57 U. S. 429, 604-606, I5 Sup. Ct. 673, 698-699. The decisions in the state courts on similar constitutional provisions are conflicting. Authorities are collected in (IgIg) 31 Op. Atty. Gen. 475, and in State ex rel. Wickham v. Nygaard (1915) I59 Wis. 396,150 N. W. 513 , holding that the Wisconsin income tax did not diminish the salary of a public officer during his term of office. Since the decision in the principal case, the acting Attorney General has ruled that the salaries of federal, judges appointed after the passage of the Revenue Act of 1918 are subject to the income tax levied by that Act. (I920) 32 Op. Atty. Gen. 248. 
hibition against a tax on exports. ${ }^{20}$ A similar rule was announced as to interstate commerce. ${ }^{21}$ The Court's differentiation of these cases is that an income tax laid, not on gross receipts, but on net proceeds remaining after all expenses were paid and losses adjusted, does not directly burden the business, but only indirectly and remotely affects it. It does not seem clear why an indirect and remote effect is not permissible in one class of cases while it is in another. ${ }^{22}$

The effects of the Court's broad holding are serious. Not merely is a large and growing field of revenue shown to be beyond the reach of the federal government, but the whole present scheme of federal income taxation with its surtaxes increasing with the amount of income, is impracticable. The resulting effects upon business in general and upon such especially acute situations as the present lack of housing cannot be underestimated. Why should one possessing capital invest in real estate mortgages to enable a would be householder to build, when vastly more return may be obtained from a municipal bond ? ${ }^{23}$ The whole incentive of this situation is to turn capital from fields vitally necessary to everyone to fields of public works. Such works in part at least are of course desirable, but many forms of public works are non-productive and the greater security involved in investments of this character has under ordinary conditions made them sufficiently attractive to investors. To make them still more attractive is to place an incentive on governmental extravagance at the expense of productive forms of business, and at the same time the whole theory that he who has the greater income must share a greater portion of the burden of government falls to the ground, for he invests in tax-exempt securities. ${ }^{24}$

The outlook for a change in this situation is dark. The only possible change is by another constitutional amendment, and the prospects of securing the passage of such an amendment against the opposition of the states seems slight. The only compensating feature of the situation is in the notice thus given the government that the field of income taxation is not limitless and that the burdens of government must be reduced.

C. E. C.

${ }^{20}$ Peck \& Co. v. Lowe (rgI8) 247 U. S. I65, 38 Sup. Ct. 432; cf. (1918) 27 YALE LAW JouRNal, IOg6.

${ }^{21}$ United States Glue Co. v. Oak Creek (I918) 247 U. S. 321, 38 Sup. Ct. 499.

22 See Powell, Indirect Encroachnent on Federal Authority (Igrg) 32 HARv. L. Rev. 902, 926-928; also 262 Fed. 554.

${ }^{23}$ Under the present federal income tax a $4 \frac{\mathrm{T}}{2}$ per cent tax-free bond yields as much net income to a person possessing income exceeding $\$ 40,000$ as a taxable security paying 6.08 per cent. The rate increases until in the case of persons with incomes of over $\$ 1,000,000$ the $4 \% / 2$ per cent tax-free bond is as profitable as a security yielding 16.67 per cent. Kahn, Two Years of Faulty Taxation '(1920) I4, 15 .

"A Obviously federal securities must be kept tax-free in order to compete with the state and municipal securities. 